J. Amer. SOC. Hort. SCI. 117(2):328-331. 1992.

\title{
Pollen Tube Growth in Carya and Temporal Influence of Pollen Deposition on Fertilization Success in Pecan
}

\author{
Robert D. Marquard ${ }^{1}$ \\ Texas A\&M University Research and Extension Center, 1380 A\&M Circle, El Paso, TX 79927 \\ Additional index words. hickory, Carya sp., pollen competition, stigma, Carya illinoinensis
}

\begin{abstract}
In vivo pollen tube growth of pecan [Carya illinoinensis (Wangenh.) K. Koch] was estimated to be $\approx 150$ $\mu \mathrm{m} \cdot$ hour $^{-1}$ from 3 to 8 hours postpollination. Pollen tubes averaged 47, 194, 405, and $946 \mu \mathrm{m}$ after $2,3,4$, and 8 hours postpollination, respectively. Pollen tube growth was strongly influenced by temperature, and in vitro studies demonstrated pollen germination and tube growth were optimal at $27 \mathrm{C}$ for 'Cape Fear' pecan. In in vivo studies, tubes of cross-pollen did not grow significantly faster than tubes of self-pollen. Pollen tubes of water hickory [C. aquatica (Michx. f.) Nutt.] grew significantly faster than those of $C$. illinoinensis. Bitternut [C. cordiformis (Wangenh.) K. Koch] and mockernut hickory (C. tomentosa Nutt.) pollen tubes grew significantly slower on pecan stigmas than did pecan pollen. Pollen arriving first on the stigma has a decided advantage for fertilization success of pecan. The fertilization success rate of pecan pollen arriving 24 hours after first pollen arrival was $<3 \%$.
\end{abstract}

Fertilization success among pollen grains can be influenced by pollen tube growth rate, timing of pollen deposition onto the stigma, and incompatibility systems. Successful pollen tubes of Geranium sp. that reached unfertilized ovules grew significantly faster than pollen from an unselected population of pollen tubes (Hessing, 1989; Mulcahy et al., 1983). Differences in the arrival time of pollen influences fertilization success. If initial pollination occurs and fertilization is achieved in $1 \mathrm{~h}$, then pollen arriving on the stigma $1 \mathrm{~h}$ later has little if any chance for fertilization (Mulcahy and Mulcahy, 1987). Likewise, the first pollen type to arrive on receptive seed cones of Douglas fir [Pseudotsuga menziesii (Mirb.) Franco] generally is more successful than late-arriving pollen (Webber and Yeh, 1987).

Incompatibility exists in many species, causing pollen tube arrest or disorientation of foreign or self-pollen at the stigma (Burson and Young, 1983; Mosseler, 1989), style (Kho and Baer, 1968; Lansari and Iezzoni, 1990), or near the micropyle (Burson and Young, 1983; Williams et al., 1986). Pollen-stylar interactions may favor pollen grains with genotypes that give rise to more vigorous seedlings (Ottaviano et al., 1980), selective abortion among developing embryos may discriminate against some genotypes (Degani et al., 1986), and interovary competition may exist in some species (Solomon, 1988).

Pecan pollen can be germinated in vitro, provided it is rehydrated before placement on a suitable medium (Yates and Sparks, 1989). Early in vivo pollen germination is visible within $3 \mathrm{~h}$, with extensive tube growth apparent between 8 to $12 \mathrm{~h}$ (Wetzstein and Sparks, 1989). However, in vivo growth rate has not been quantified and little is known about pollen-stigma interactions among pecan clones and Carya sp. Further, the relationship between timing of pollen arrival and fertilization success in pecan has not been evaluated. Nut weight and volume in pecan are influenced by the pollen parent (Romberg and Smith, 1946; Sparks and Madden, 1985; Wolstenholme, 1969). Therefore, information about pollen-stigma interactions and competition among pollen arriving at different times would enhance our understanding of pecan pollination dynamics. Experiments

Received for publication 8 May 1991. Accepted for publication 9 Oct. 1991. The cost of publishing this paper was defrayed in part by the payment of page charges. Under postal regulations, this paper therefore must be hereby marked advertisement solely to indicate this fact.

${ }^{1}$ Current address: The Holden Arboretum, 9500 Sperry Rd., Mentor, OH 44060. were designed to quantify pollen tube growth and answer the following questions: 1) what is the in vivo growth rate of pollen tubes and how is growth rate influenced by temperature; 2 ) are there differences in tube growth among pollen sources; and 3) how do temporal differences in time of pollen arrival on the stigma influence fertilization success?

\section{Materials and Methods}

Field experiments were conducted mainly by bagging female flower clusters of pecan before receptivity (Smith and Romberg, 1940). Pollen of a specific type was injected by syringe through the pollination bags and onto receptive stigmas. Female flowers were removed from the cluster after the prescribed length of time had elapsed and fixed in a formalin-acetic acid (FAA) solution (Berlyn and Miksche, 1976) for later microscopic observation. To observe in vivo pollen tube growth, stigmas were cut from the subtending ovaries enclosed by the floral envelope, softened in $8 \mathrm{~N} \mathrm{NaOH}$ for 8 to $18 \mathrm{~h}$ at room temperature, washed $10 \mathrm{~min}$ in distilled water $(3 \times)$, bisected, and squashed between coverslip and microscope slide in $1 \%$ aniline blue prepared in $0.1 \mathrm{~N}$ phosphate buffer (Rho and Baer, 1968). Pollen tubes were viewed with ultraviolet (UV) light from an Olympus BHT microscope (Lake Success, N.Y.) equipped with a mercury lamp and BP-490 exciter filter with barrier filters L-420 and 0-515. Appropriate fields containing the longest intact tubes were photographed. Pollen tube length was digitized from photographs using a Sigma Scan digitizing tablet and software (Jandel Scientific; Corte Madera, Calif.) calibrated to a stage micrometer. In general, one to four tubes were measured from each photograph. Pollen tubes of various lengths were observed, and, unless noted, the reported data are an average tube length from the longest one-third of measured tubes. Pollinations conducted in the field included three to six flower clusters per parental combination. Most data for a parental combination were collected from pollen tubes growing on two to eight female flowers.

Pollen tube growth rate of pecan (Expt. 1). Under field conditions in 1988, pistillate flowers of 'Western Schley', 'Cheyenne', and 'Cape Fear' were pollinated with 'Wichita' pollen that was used within 7 days of collection. Flowers were pollinated in the morning and harvested at $0,0.5,1,2,4,8$, and $24 \mathrm{~h}$ postpollination. Pollen tubes were detected and measured as described above. 
The influence of temperature on in vivo pollen tube growth was evaluated under controlled conditions. Bagged and receptive female flower clusters of 'Western Schley' were detached and brought into the laboratory. Female flowers were removed from the peduncle and individually placed into $1.5-\mathrm{ml}$ microfuge tubes with conical bottoms and containing $50 \mu \mathrm{l}$ of water. The tubes were placed in one of three aluminum blocks $(10 \times$ $7.5 \times 5 \mathrm{~cm})$ that were drilled to accept these tubes. Holes in the block were filled with water to increase conduction between block and microfuge tube. Each block was placed on a large thermal gradient aluminum plate $(2.5 \times 61 \times 133 \mathrm{~cm})$ where a temperature gradient was maintained by warming one end by hot plate and cooling the other with compressed freon, similar to the system described by Hensley et al. (1982). Hot plate and compressor were thermostatically controlled. Aluminum blocks containing tubes and flowers were placed on the plate at temperatures between 20 and $30 \mathrm{C}$ and remained in place for a 1-h equilibration period. For each block, the temperature directly above the stigma was measured by placement of three $0.51-\mathrm{mm}$ (24-gauge) copper-constantan thermocouples into each of three microfuge tubes. Temperatures were automatically recorded at 9-min intervals by an Omnidata polycorder (Logan, Utah). After $1 \mathrm{~h}$, stigmas were lightly pollinated with 'Cheyenne' pollen. Flowers were harvested $3 \mathrm{~h}$ postpollination, fixed, and tube growth quantified as described above.

To refine the evaluation of temperature on pollen germination and tube growth, an in vitro system was developed using a solid medium. Pollen was hydrated for $3 \mathrm{~h}$ on microscope slides above a saturated potassium sulfate solution (Yates and Sparks, 1989). A $2 \%$ agarose gel was prepared to a $\mathrm{pH}$ of 5.5 and included $0.01 \%$ boric acid, $0.03 \%$ calcium nitrate, $0.02 \%$ magnesium sulfate, $0.01 \%$ potassium nitrate, and $15 \%$ sucrose. Agarose gels have the advantage of a relatively high melting point in comparison with other solidifying agents. The agarose solution was heated just until boiling, cast into 50-mm-diameter petri dishes, and cooled to ambient temperature. Hydrated pollen was then lightly dusted on the surface. Petri dishes were placed on the thermal gradient plate described above at temperatures from $\approx 15$ to $35 \mathrm{C}$. Medium temperatures were measured by thermocouples with junctions contacting the media. Percent germination and pollen tube growth for 'Cape Fear' pollen were evaluated by light microscopy. Germination counts were made, and tube lengths were measured directly from photographs as described above.

Pollen was evaluated twice and a least squares polynomial regression was used to generate a cubic relationship between temperature and germination or pollen tube length. Expected values from the cubic equation were combined to estimate optimum temperature for germination and pollen tube growth for 'Cape Fear' pollen.

Pollen-stigma interactions (Expt. 2). The nine possible combinations of controlled crosses were made between 'Cape Fear', 'Western Schley', and 'Cheyenne'. Flowers were harvested and fixed 4 or $5.5 \mathrm{~h}$ postpollination. Pollen from each cultivar was collected on the same day and used in pollinations within 7 days of collection. Tube growth was evaluated as described above. Experiments were conducted once in 1988 and twice in 1990.

In 1989, pollen was collected from water hickory, bitternut hickory, nutmeg hickory [C. myristiciformis (Michx. f.) Nutt.], mockernut hickory, and large-leafed walnut (Juglans microcarpa Berl.) and used in controlled pollinations. 'Wichita' pollen was used for comparison. Various pecan clones served as the female parent, and each of the six pollen types was used individually as the male parent. Flowers were harvested at 4 or $5.5 \mathrm{~h}$ postpollination. Tube growth after interspecific pollinations is reported as percent growth of 'Wichita' pollen tubes made on the same tree at the same time as hickory and walnut pollen.

Temporal differences in pollen arrival and fertilization success (Expt. 3). Female flowers of 'Western Schley' and 'Cape Fear' were bagged and two pollen sources selected based on availability of flowers and pollen. Pecan is polymorphic for isozymes of malate dehydrogenase, and one locus (Mdh-1) is controlled by four alleles (Marquard, 1987, 1989). The rate of fertilization success of two pollen types arriving at different times was evaluated from mature fruit using a simply inherited isozyme marker. All parents included in the study were homozygous for $M d h-1$. The two pollen types (arbitrarily designated as A and B) used per female parent were complementary in genotype so that the successful male parent could be unequivocally determined from mature fruit tissue. Cotyledon tissue has the same isozyme banding pattern as is eventually expressed in leaf tissue of the same propagule (Marquard and Skorpenske, 1989).

Three pollination treatments were evaluated: 1) a 1:1 mixture (w/w) of the two pollen types (A and B) applied to receptive stigmas; 2) type A pollen applied alone followed $4 \mathrm{~h}$ later by type B pollen; 3) type A pollen applied alone followed $24 \mathrm{~h}$ later by type B pollen. Mature fruit were harvested in the fall, and the successful pollen parent (type A or B) of each fruit was determined by genotyping for $M d h-1$ by starch gel electrophoresis. For example, the $M d h-1$ genotype of 'Western Schley' and 'Pawnee' are $b b$ and $a a$, respectively. All progeny produced from 'Western Schley' pollinated with 'Pawnee' pollen will have an $a b$ genotype, whereas self-pollinated 'Western Schley' will have a $b b$ genotype. This experiment was repeated with four parental combinations (Table 1). Data are corrected so that the second pollen used (type B) is assigned a relative fertilization success value of 100 when pollen types are mixed 1:1 and used simultaneously for pollination. Conditions to run the starch gels and elucidate malate dehydrogenase have been reported (Marquard, 1987; Marquard and Skorpenske, 1989).

Table 1. Relative success rate of type B pollen. All female flowers either received both pollen types simultaneously $(0 \mathrm{~h})$, or type A pollen followed by $\mathrm{B}$ pollen $4 \mathrm{~h}$ later, or type A pollen followed by $\mathrm{B}$ pollen $24 \mathrm{~h}$ later. Data are corrected so relative success rate of B pollen at time zero is 100 .

\begin{tabular}{|c|c|c|c|c|c|c|}
\hline \multirow{3}{*}{$\begin{array}{l}\text { Female } \\
\text { parent }\end{array}$} & \multirow{3}{*}{$\begin{array}{l}\text { Study } \\
\text { year }\end{array}$} & \multirow{2}{*}{\multicolumn{2}{|c|}{$\begin{array}{l}\text { Pollen type } \\
\text { and clone }\end{array}$}} & \multicolumn{3}{|c|}{$\begin{array}{l}\text { Relative success } \\
\text { of B pollen }\end{array}$} \\
\hline & & & & \multicolumn{3}{|c|}{$\begin{array}{c}\text { Delay in } \\
\text { application }(h)\end{array}$} \\
\hline & & $\mathrm{A}$ & B & 0 & 4 & 24 \\
\hline Western Schley & 1987 & Western ${ }^{z}$ & Pawnee & 100 & 33 & 0 \\
\hline Western Schley & 1987 & Pawnee & Western & 100 & 38 & 5 \\
\hline Cape Fear & 1988 & Western & $61-6-28^{y}$ & 100 & 46 & 5 \\
\hline Western Schley & 1988 & Cape Fear & $61-6-28$ & 100 & 23 & 0 \\
\hline Mean & & & & 100 & 35 & 3 \\
\hline
\end{tabular}

${ }^{\mathrm{z}}$ Western refers to 'Western Schley'.

${ }^{y}$ Clone 61-6-28 is a U.S. Dept. of Agriculture cross between 'Starking Hardy Giant' and 'Mohawk' with an aa genotype for Mdh-1. 'Western Schley' and 'Cape Fear' have a $b b$ genotype and 'Pawnee' has an $a a$ genotype for $M d h-1$. 


\section{Results and Discussion}

In vivo pollen tube growth rate. Pollen did not have sufficient time to rehydrate and germinate extensively in vivo after $1 \mathrm{~h}$ on receptive stigmas. Most pollen grains washed off the stigma if harvested within $1 \mathrm{~h}$ postpollination when fixed in FAA. Limited tube growth was observed at $2 \mathrm{~h}$ postpollination, although the average tube length did not yet exceed the diameter of pecan pollen [54 $\mu \mathrm{m}$ (Stone, 1963)] (Table 2). Tubes were too long to accurately measure microscopically at $24 \mathrm{~h}$ postpollination. Average tube length of 'Wichita' pollen on three cultivars after 2, 3, 4, and $8 \mathrm{~h}$ postpollination was 47, 194, 404, and $945 \mu \mathrm{m}$, respectively. Pollen tube growth rate averaged $\approx 150 \mu \mathrm{m} \cdot \mathrm{h}^{-1}$ between 3 and $8 \mathrm{~h}$ postpollination. No differences were detected among the responses of 'Wichita' pollen on three distinct female cultivars. Binucleate pollen generally has a lag phase in early tube growth. Pollen tube growth of the binucleate Petunia was $0.3 \mathrm{~mm} \cdot \mathrm{h}^{-1}$, whereas the trinucleate pollen of Silene dioica (L.) Clairv. grew nearly $0.75 \mathrm{~mm} \cdot \mathrm{h}^{-1}$ without a lag phase (Mulcahy and Mulcahy, 1983). Carya pollen is binucleate (Sedgley and Griffin, 1989), and the distance from the stigma to the embryo sac is several millimeters. If we conservatively estimate pollen tube growth of pecan to be $150 \mu \mathrm{m} \cdot \mathrm{h}^{-1}$, pollen tubes may reach the micropyle in less than $24 \mathrm{~h}$. Pollen tubes must grow through several millimeters of stigmatic tissue, and growth rate through the subtending tissue may be different from what was observed in stigmatic tissue. Moreover, pistillate flowers may not be ready for fertilization at the time of pollination (Woodroof and Woodroof, 1926).

Temperature dramatically influenced early in vivo pollen tube growth rate of 'Cheyenne' pollen on 'Western' stigmas $3 \mathrm{~h}$ postpollination (Table 3). Under the temperatures tested, a moderate temperature (26C) was better than relatively high (30C) or low (22C) temperatures. Pollen tubes were more than three times longer at $26 \mathrm{C}$ than at $22 \mathrm{C}$. The optimum temperature for germination and tube growth from in vitro germination of 'Cape Fear' pollen on a solid medium was 27C (Fig. 1). In contrast, walnut pollen germinated best at somewhat higher temperatures [Juglans regia L. at $28 \mathrm{C}$ and J. nigra L. at 32C (Luza et al.,

Table 2. Maximum tube growth of 'Wichita' pollen on pistillate flowers of 'Western', 'Cheyenne', and 'Cape Fear' harvested at various times. Tube lengths represent the average of the longest three tubes for each combination and time that were measured.

\begin{tabular}{lrrrrrrr}
\hline \hline & \multicolumn{7}{c}{ Pollen tube length $(\mu \mathrm{m})$} \\
\cline { 2 - 8 } Female & 0 & 0.5 & 1 & 2 & 3 & 4 & \multicolumn{1}{c}{8} \\
\cline { 2 - 8 } parent & 0 & 0 & 22 & 77 & 164 & 355 & 995 \\
Western & 0 & 0 & 3 & 24 & 236 & 568 & 756 \\
Cheyenne & 0 & 0 & 3 & 39 & 182 & 291 & 1086 \\
Cape Fear & 0 & 0 & 9 & 47 & 194 & 405 & 946 \\
Mean & 0 &
\end{tabular}

Table 3. In vivo pollen tube growth of 'Cheyenne' pollen on 'Western' stigmas after $3 \mathrm{~h}$ various temperatures. Mean tube length represents the longest four tubes.

\begin{tabular}{lc}
\hline \hline $\begin{array}{l}\text { Avg ambient } \\
\text { temp }\left({ }^{\circ} \mathrm{C}\right)\end{array}$ & $\begin{array}{c}\text { Mean pollen tube } \\
\text { growth }(\mu \mathrm{m}) \pm \mathrm{SD}^{\mathrm{z}}\end{array}$ \\
\hline 22.3 & $150 \pm 48$ \\
25.5 & $536 \pm 66$ \\
29.9 & $367 \pm 17$ \\
\hline
\end{tabular}

${ }^{\mathrm{z}}$ All means are significantly different from each other based on $t$ test $(P=0.01)$.

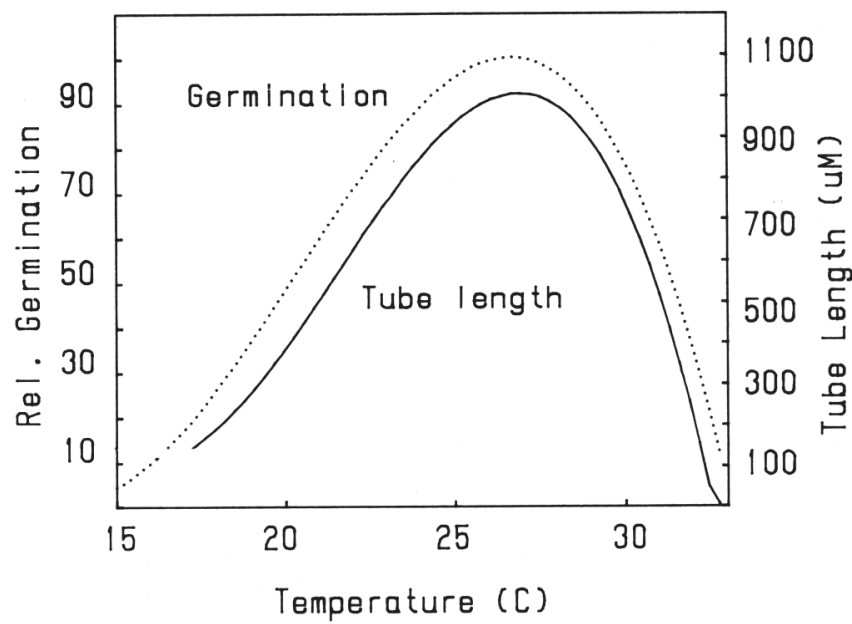

Fig. 1. Influence of temperature on in vitro growth rate of pollen tubes and relative germination rate of 'Cape Fear' pecan pollen. Equations to describe temperatures' $(\mathrm{X})$ influence on pollen tube growth $\left(\mathrm{Y}_{1}\right)$ and germination rate $\left(\mathrm{Y}_{2}\right)$ are $\mathrm{Y}_{1}(\mu \mathrm{m})=11854$ $1825 X+90.78 X^{2}-1.409 X^{3}$ and $Y_{2}(\%)=592.7-103.3 X+$ $5.6735 X^{2}-0.09348 X^{3}$.

Table 4. Mean pollen tube length of nine pollen-stigma combinations using 'Western', 'Cape Fear', and 'Cheyenne' from three independent experiments (flowers were harvested an average of $4.5 \mathrm{~h}$ postpollination).

\begin{tabular}{lccc}
\hline \hline & \multicolumn{3}{c}{ Pollen tube length $(\mu \mathrm{m})$} \\
\cline { 2 - 4 } Pollen & \multicolumn{3}{c}{ Female parent } \\
\cline { 2 - 4 } parent & Cane Fear & Western & Cheyenne \\
\hline Cape Fear & 573 & 566 & 492 \\
Western & 486 & 583 & 663 \\
Cheyenne & 381 & 605 & 447 \\
\hline
\end{tabular}

1987)]. However, different optima may exist among pecan cultivars.

Pollen-stigma interactions. Intraspecific pollen tube growth of pecan was not statistically different among three test cultivars (Table 4). On average, 'Cape Fear', 'Western', and 'Cheyenne' pollen tubes had elongated 480, 585, and $534 \mu \mathrm{m}$, respectively, at $4.5 \mathrm{~h}$ postpollination. Differences in ambient temperatures influenced by microenvironment (sun or shaded, bagged floral clusters) may account for some of the observed variability in pollen tube growth. Self-pollen was not discriminated against based on early pollen tube growth (Table 4). However, selfing increases fruit abortion in pecan, suggesting some postzygotic discrimination (Sparks and Madden, 1985). Similarly, Degani et al. (1986) demonstrated that some genotypes in avocado are selectively eliminated during fruit maturation.

Significant differences in short-term pollen tube growth were observed after interspecific pollination (Table 5). Pollen of water hickory grew better than 'Wichita' pollen on pecan stigmas. Water hickory is believed to be closely related to pecan based on the combination of pollen size and stomatal area (Stone, 1963). Natural and artificial hybridization between pecan and water hickory can occur (Stauder et al., 1984), and putative hybrids exist among various Carya species (Thompson and Young, 1985). Pollen from bitternut and mockernut hickory on pecan stigmas tended to grow more slowly than conspecific pollen (Table 5).

Pecan, nutmeg, and bitternut hickory are members of the Apocarya section, whereas mockernut hickory is a member of 
Table 5. Relative tube growth of Carya and Juglans pollen on stigmas of $C$. illinoinensis. Data are presented as the percent tube growth of a conspecific cross of $C$. illinoinensis.

\begin{tabular}{lc}
\hline \hline Species & $\begin{array}{c}\text { Relative pollen } \\
\text { tube growth }(\%)^{\mathbf{z}}\end{array}$ \\
\hline C. aquatica & $141 \mathrm{a}$ \\
C. illinoinensis & $100 \mathrm{~b}$ \\
C. myristiciformis & $93 \mathrm{bc}$ \\
C. cordiformis & $67 \mathrm{c}$ \\
C. tomentosa & $55 \mathrm{~d}$ \\
J. microcarpa & $35 \mathrm{~d}$ \\
\hline \hline
\end{tabular}

${ }^{\mathrm{z}}$ Mean separation by Duncan's multiple range test, $P=0.05$.

the Carya section (Grauke and Pratt, 1986). Pollen from mockernut hickory grew the slowest of the hickory pollens that were evaluated. Pollen tubes of Juglans microcarpa elongated only $35 \%$ the length of conspecific pollen. This result suggests some relationship may exist between phylogenetic relatedness and pollen tube growth rate. Similar methods were used to assess phylogeny in Salix (Mosseler, 1989). However, pollen from other hickory or walnut species may have inherently different pollen tube growth rates.

Interspecific hybrids have been reported between pecan and various hickory species (Thompson and Young, 1985). Of the four hickory pollen parents tested, $C$. myristiciformis has not yet been verified to hybridize with pecan. Based on relative pollen tube growth, hybridization between these two species should be possible (Table 5). The natural range of $C$. myristiciformis is relatively small and likely reduces the opportunity for natural hybridization with pecan.

Temporal differences in pollen arrival and fertilization success. Timing of pollen arrival influenced fertilization success. On average, pollen that arrived 4 or $24 \mathrm{~h}$ after initial pollen impaction had a respective $35 \%$ and $3 \%$ likelihood for fertilization success (Table 1). Reduced fertilization success of latearriving pollen may be caused by degeneration of the stigmatic surface of pecan 24 to $48 \mathrm{~h}$ after initial pollen impaction (Wetzstein and Sparks, 1989). However, if pistillate flowers are not ready for fertilization at the time of pollination, as suggested by Woodroof and Woodroof (1926), the degeneration in the stigma may contribute more significantly to the exclusion of the second-arriving pollen. Success of supplemental pollination (SP) as a cultural treatment, therefore, depends on a properly timed release of pollen. If SP were considered as a cultural practice to overcome high rates of self-pollination, supplemental pollen must arrive early in the period of receptivity or when native, self-pollen is at a low frequency in the orchard. SP treatments when self-pollen predominates in the orchard may be largely unsuccessful due to dilution by native pollen in the orchards.

Wind-pollinated species are copious pollen producers. Fifteen liters of tightly packed pecan catkins that are properly collected can yield 50 to $75 \mathrm{~g}$ of pollen (personal observation); $20 \mathrm{~g}$ of pollen can be readily collected from a few small trees, and this quantity has been the recommended pollen dose per hectare of orchard [50 g/acre (McClure, 1986)].

\section{Summary}

Pollen tube growth after interspecific pollination may be related to phylogenetic relatedness. Pollen from the closely related water hickory grew faster than conspecific pecan pollen, whereas the distantly related mockernut hickory grew the slowest. Differences in timing of pollen arrival significantly influenced fertilization success.

\section{Literature Cited}

Berlyn, G.P. and J.P. Miksche. 1976. Botanical microtechnique and cytochemistry. Iowa State Univ., Ames.

Burson, B.L. and B.A. Young. 1983. Pollen-pistil interactions and interspecific-incompatibility among Panicum antidotale, P. coloratum, and P. deustum. Euphytica 32:397-405.

Degani, C., A. Goldring, S. Gazit, and U. Lavi. 1986. Genetic selection during the abscission of avocado fruitlets. HortScience 21:1187-1188.

Grauke, L.J. and J.W. Pratt. 1986. A field guide to the hickories of North America. Proc. Northern Nut Growers Assn. 77:123-153.

Hensley, D.L., J.B. Masiunas, and P.L. Carpenter. 1982. An inexpensive temperature gradient system. HortScience 17:585-586.

Hessing, M.B. 1989. Differential pollen tube success in Geranium caespitosum. Bot. Gaz. 150:404-410.

Kho, Y.O. and J. Baer. 1968. Observing pollen tubes by means of fluorescence. Euphytica 17:298-302.

Lansari, A. and A. Iezzoni. 1990. A preliminary analysis of self incompatibility in sour cherry. HortScience 25:1636-1638.

Luza, J.G., V.S. Polito, and S.A. Weinbaum. 1987. Staminate bloom date and temperature response of pollen germination and tube growth in two walnut (Juglans) species. Amer. J. Bot. 74:1898-1903.

Marquard, R.D. 1987. Isozyme inheritance, polymorphism, and stability of malate dehydrogenase and phosphoglucose isomerase in pecan. J. Amer. Soc. Hort. Sci. 112:717-721.

Marquard, R.D. 1989. Rare allozymes of malate dehydrogenase in pecan. HortScience 24:156.

Marquard, R.D. and R.G. Skorpenske. 1989. Expression of heritable biochemical markers from various pecan tissues. Euphytica 42:65-70.

McClure, C.E. 1986. Some experience in the collecting, handling, and application of fruit and nut pollens. Proc. Western Pecan Conf. 20:38.

Mulcahy, D.L., P.S. Curtis, and A.A. Snow. 1983. Pollen competition in a natural population, p. 330-337. In: C.E. Jones and R.J. Little (eds.). Handbook of experimental pollination biology. Van Nostrand Reinhold, New York.

Mulcahy, D.L. and G.B. Mulcahy. 1987. The effects of pollen competition. Amer. Scientist 75:44-50.

Mulcahy, G.B. and D.L. Mulcahy. 1983. A comparison of pollen tube growth in bi- and trinucleate pollen, p. 29-33. In: D.L. Mulcahy and E. Ottaviano (eds.). Pollen: Biology and implications for plant breeding. Elsevier Publishing Co., New York.

Mosseler, A. 1989. Interspecific pollen-pistil incongruity in Salix. Can. J. For. Res. 19:1161-1168.

Ottaviano, E., M. Sari-Gorla, and D.L. Mulcahy. 1980. Pollen tube growth rates in Zen mays; Implications for genetic improvement of crops. Science 210:437-438.

Romberg, L.D. and C.L. Smith. 1946. Effects of cross-pollination, self-pollination and sib-pollination on the dropping, the volume and the kernel development of pecan nuts and on the vigor of the seedlings. Proc. Amer. Soc. Hort. Sci. 47:130-138.

Sedgley, M. and A.R. Griffin. 1989. Sexual reproduction of tree crops. Academic, San Diego.

Smith, C.L. and L.D. Romberg. 1940. Stigma receptivity and pollen shedding in some pecan varieties. J. Agr. Res. 60:551-564.

Solomon, B.P. 1988. Patterns of pre- and post-fertilization resource allocation within an inflorescence: Evidence for interovary competition. Amer. J. Bot. 75:1074-1079.

Sparks, D. and G.D. Madden. 1985. Pistillate flower and fruit abortion in pecan as a function of cultivar, time, and pollination. J. Amer. Soc. Hort. Sci. 110:219-223.

Stauder, A.F., J.R. Toliver, and N. Keith. 1984. The reliability of selected morphological characteristics in identifying Carya $\times$ lecontei through controlled pollination experiments. For. Sci. 30:475-483.

Stone, D.E. 1963. Pollen size in hickories (Carya). Brittonia 15:208-214.

Thompson, T.E. and F. Young. 1985. Pecan cultivars-Past and present. Texas Pecan Growers Assn., College Station.

Webber, J.E. and F.C.H. Yeh. 1987. Test of the first-on, first-in pollination hypothesis in coastal Douglas-fir. Can J. For. Res. 17:63-68.

Wetzstein, H.Y. and D. Sparks. 1989. Stigma-pollen interactions in pecan. J. Amer. Soc. Hort. Sci. 114:355-359.

Williams, E.G., V. Kaul, J.L. Rouse, and B.F. Palser. 1986. Overgrowth of pollen tubes in embryo sacs of Rhododendron following interspecific pollinations. Austral. J. Bot. 34:413-423.

Wolstenholme, B.N. 1969. Effects of self- and cross-pollination on fruit set and nut drop of the pecan at Pietermaritzburg. Agroplantae 1:189-194.

Woodroof, J.G. and N.C. Woodroof. 1926. Fruit-bud differentiation and subsequent development of the flowers in the hicoria pecan. J. Agr. Res. 33:677-685.

Yates, I.E. and D. Sparks. 1989. Hydration and temperature influence in vitro germination of pecan pollen. J. Amer. Soc. Hort. Sci. 114:599-605. 